\title{
Hydrogeochemical analysis and evaluation of surface water quality of Pratapgarh district, Uttar Pradesh, India
}

\author{
Ashwani Kumar Tiwari ${ }^{1,2}$ - Abhay Kumar Singh ${ }^{1}$ Amit Kumar Singh ${ }^{2}$. \\ M. P. Singh ${ }^{3}$
}

Received: 19 February 2015/Accepted: 7 July 2015/Published online: 23 July 2015

(c) The Author(s) 2015. This article is published with open access at Springerlink.com

\begin{abstract}
The hydrogeochemical study of surface water in Pratapgarh district has been carried out to assess the major ion chemistry and water quality for drinking and domestic purposes. For this purpose, twenty-five surface water samples were collected from river, ponds and canals and analysed for $\mathrm{pH}$, electrical conductivity, total dissolved solids (TDS), turbidity, hardness, major cations $\left(\mathrm{Ca}^{2+}\right.$, $\mathrm{Mg}^{2+}, \mathrm{Na}^{+}$and $\left.\mathrm{K}^{+}\right)$, major anions $\left(\mathrm{HCO}_{3}^{-}, \mathrm{F}^{-}, \mathrm{Cl}^{-}\right.$, $\mathrm{NO}_{3}{ }^{-}, \mathrm{SO}_{4}{ }^{2-}$ ) and dissolved silica concentration. The analytical results show mildly acidic to alkaline nature of surface water resources of Pratapgarh district. $\mathrm{HCO}_{3}{ }^{-}$and $\mathrm{Cl}^{-}$are the dominant anions, while cation chemistry is dominated by $\mathrm{Na}^{+}$and $\mathrm{Ca}^{2+}$. The statistical analysis and data plotted on the Piper diagram reveals that the surface water chemistry is mainly controlled by rock weathering with secondary contributions from agriculture and anthropogenic sources. $\mathrm{Ca}^{2+}-\mathrm{Mg}^{2+}-\mathrm{HCO}_{3}^{-}, \mathrm{Ca}^{2+}-\mathrm{Mg}^{2+}-\mathrm{Cl}^{-}$ and $\mathrm{Na}^{+}-\mathrm{HCO}_{3}{ }^{-}-\mathrm{Cl}^{-}$are the dominant hydrogeochemical facies in the surface water of the area. For quality assessment, values of analysed parameters were compared with Indian and WHO water quality standards, which shows that the concentrations of TDS, $\mathrm{F}^{-}, \mathrm{NO}_{3}{ }^{-}, \mathrm{Na}^{+}, \mathrm{Mg}^{2+}$ and total hardness are exceeding the desirable limits in some water samples. Water Quality Index (WQI) is one of the most effective tools to communicate information on the quality
\end{abstract}

Ashwani Kumar Tiwari

ashwani.enviro@gmail.com

1 CSIR-Central Institute of Mining and Fuel Research, Barwa Road, Dhanbad 826015, India

2 Department of Environmental Science, V.B.S. Purvanchal University, Jaunpur 223101, India

3 Centre of Biotechnology, University of Allahabad, Allahabad 211002, India of any water body. The computed WQI values of Pratapgarh district surface water range from 28 to 198 with an average value of 82 , and more than half of the study area is under excellent to good category.

Keywords Pratapgarh - Major ion chemistry · Hydrogeochemical facies - Surface water quality - PCA . WQI · GIS

\section{Introduction}

The availability of fresh water is potentially one of the most pervasive crises of the coming century. Water-related decisions will determine the future of major ecosystems, health of regional economies and political stability of the nations. Water quality plays an important role in promoting agricultural production and standard of human health. Water quality is much depending on the desired use of water, hence different uses require different criteria of water quality assessment as well as standard method for reporting and comparing result of water analysis (Babiker et al. 2007). Therefore, understanding of the chemical composition of water is essential for evaluating its suitability for different purposes. Further, it is possible to understand the change in quality due to water-rock interaction (weathering) or any type of anthropogenic influences (Todd 1980). In the last few decades, due to rapid industrialization and increase in human population, there has been a tremendous pressure on the demand of fresh water (Singh et al. 2014; Chandra et al. 2014). Water pollution not only affects water quality but also threats human health, economic development and social prosperity (Milovanovic 2007). A large population in India still live in absolute poverty in both urban and rural areas, lacking 
access to clean drinking water and basic sanitation. Access to safe drinking water remains an urgent necessity, as $30 \%$ of urban and $90 \%$ of rural Indian population still depend completely on untreated surface or groundwater resources (Kumar et al. 2005).

Water Quality Index (WQI), a well-known method for assessing water quality offers a simple, stable and reproducible unit of measurement and communicates information of water quality to the policy makers and concerned citizens (Singh et al. 2013a). Statistical methods help to explain the correlation among large number of populations and also to reduce the number of variables into small number of factors without the loss of essential information (Nadiri et al. 2013). WOI and statistical methods are very useful and efficient for assessing the quality of water and for communicating the information on overall quality of water (Srivastava et al. 2011; Yadav et al. 2012; Verma and Singh 2013; Ravikumar et al. 2013; Kumar et al. 2014; Tiwari et al. 2014; Parmar and Bhardwaj 2014; Singh and Kamal 2014; Krishna Kumar et al. 2014; Singh et al. 2015a; Yadav et al. 2015; Nasri et al. 2015; Singh et al. 2015b; Okiongbo and Douglas 2015; Tiwari et al. 2015; Singh et al. 2015c).

Geographical information system (GIS) is a powerful tool for developing solutions for water resource problems, assessing water quality, determining water availability, zone mapping and risk assessment on environmental health problems on a local to regional scale (Tjandra et al. 2003; Ghosh et al. 2015). GIS is widely used for collecting diverse spatial data and for overlay analysis in spatial register domain to represent spatially variable phenomena (Bonham-Carter 1996; Gupta and Srivastava 2010). GIS-based, simple and robust WQI is an essential tool for rapid transfer of information to water resources managers and public and useful for taking quick policy decisions (Srivastava et al. 2011; Singh et al. 2013b; Tiwari et al. 2014). Recently, several studies have been made on the use of GIS and preparing spatial distribution map of water quality parameters (Chatterjee et al. 2010; Srivastava et al. 2011; Srinivas et al. 2013; Singh et al. 2013c; Selvam et al. 2013; Tiwari and Singh 2014; Gnanachandrasamy et al. 2014; Tiwari et al. 2014). In the present work, attempts have been made to evaluate the water quality of surface water resources in Pratapgarh district by using conventional hydrogeochemical methods, WQI and preparing thematic maps for the various water quality parameters. The study provides baseline information about water quality for the welfare of the society and that may also help in future water resource planning for the area.

\section{Study area}

Pratapgarh is one of the oldest district of Uttar Pradesh, lies between $25^{\circ} 34^{\prime}$ and $26^{\circ} 11^{\prime} \mathrm{N}$ latitudes, and $81^{\circ} 19^{\prime}$ and $82^{\circ} 27^{\prime} \mathrm{E}$ longitudes and covers total geographical area of $3730 \mathrm{~km}^{2}$ (Fig. 1). Pratapgarh district has seventeen administrative blocks and total population of the district is around 3,173,752 (India Census, 2011). The study area has a semi-arid to arid climate characterized by a hot summer and cold winter. January is the coldest month of the year with the mean daily maximum and minimum temperature of 24.1 and $7.5^{\circ} \mathrm{C}$, respectively. May is the hottest months with mean daily maximum temperature of $42.5^{\circ} \mathrm{C}$ and minimum of $26.4{ }^{\circ} \mathrm{C}$. The average annual rainfall of the district is around $1000 \mathrm{~mm}$ and about $90 \%$ of the rainfall takes place during June to September months. Agriculture is the main activity carried out in this area.

Sai is the most important river flowing from west to east direction through heartland of the Pratapgarh district. This river irrigates northern and southern parts of Pratapgarh district and meets Gomti River at downstream in the Jaunpur district. During rainy season, Sai River often gets flooded and during summer, narrow strip of water flows through masses of sand. The average altitude of the district is 137 metre from mean sea level and the land slopes gently from north-west to south-east. Pratapgarh district has no exploitable minerals except sands excavation along the rivers Ganga and Sai.

Geologically, the whole district is covered with unconsolidated Quaternary alluvium deposits. The formations are chiefly composed of sand, sandy clay, clay with varying amount of kankar (calcareous nodules). The older alluvium generally occupies a larger part of the area away from flood plains of the Ganga and Sai Rivers, whereas newer alluvium generally occupies the low-lying areas and is restricted to flood plains mainly in the narrow belt along the course of rivers. The older alluvium is made up of massive beds of clay of pale reddish brown colour, very often yellowish with kankar (calcrete) present in between the clay layers. The newer alluvium is light coloured and poor in calcareous matter. The upper layer of alluvium is composed of sandy loam and clayey loam.

\section{Materials and methods}

For the assessment of surface water quality of Pratapgarh district, a systematic sampling was carried out during June 2009. Representative twenty-five surface water samples were collected from river, ponds and canals both in rural and urban area (Fig. 1 and Table 1). Surface water samples were collected in pre-washed one-litre polyethylene narrowmouth bottles after rinsing the bottles for 2-3 times with 


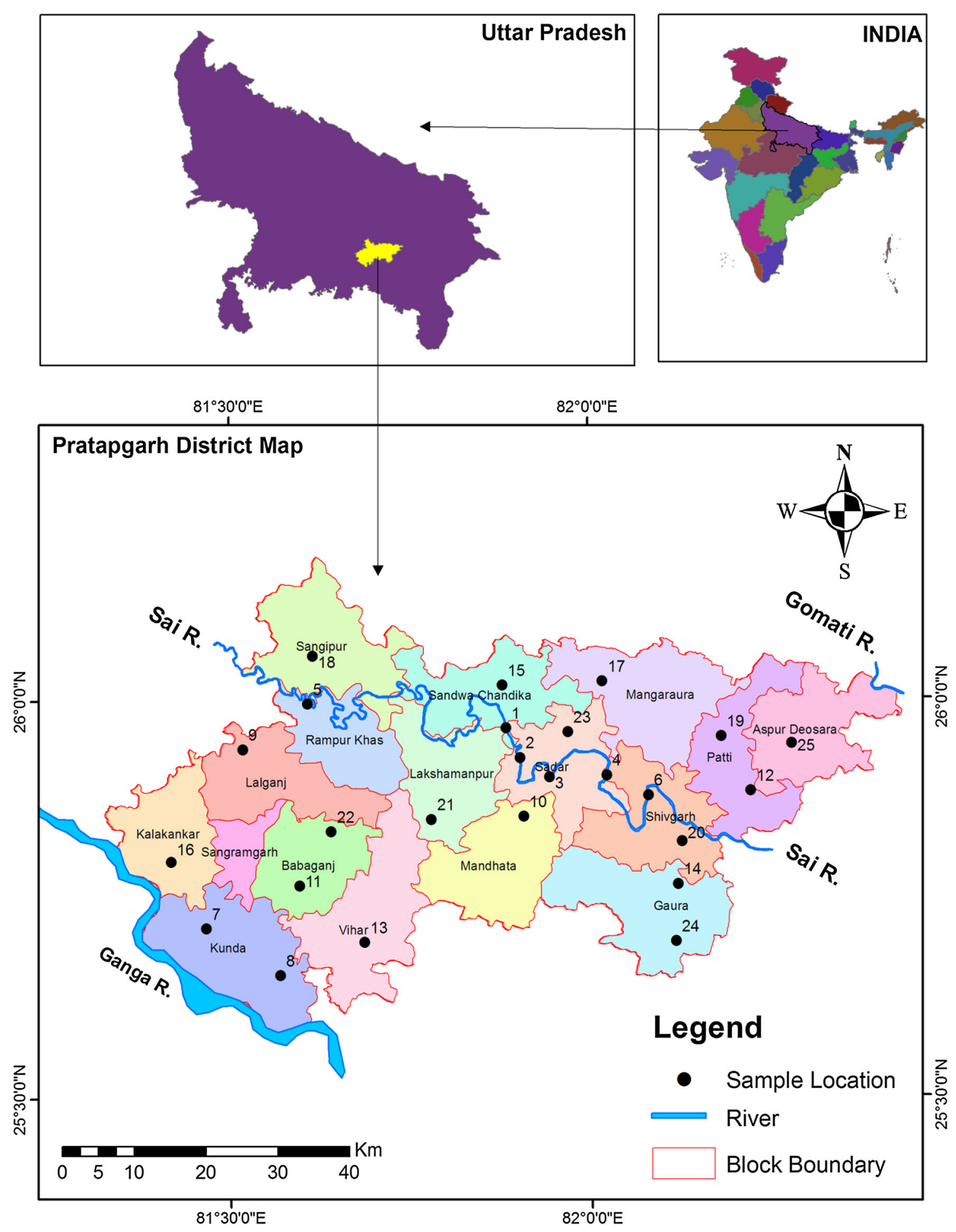

Fig. 1 Location map of Pratapgarh district showing sampling sites

water to be sampled. $\mathrm{pH}$ and electrical conductivity (EC) values were measured in the field using a portable conductivity and $\mathrm{pH}$ metre. In the laboratory, the water samples were filtered through $0.45-\mu \mathrm{m}$ Millipore membrane filters to separate suspended sediments. Acid titration and molybdosilicate methods were used to determine the concentration of bicarbonate and dissolved silica, respectively, in surface water (APHA 1998). Concentration of major anions $\left(\mathrm{F}^{-}\right.$, $\mathrm{Cl}^{-}, \mathrm{NO}_{3}{ }^{-}$and $\mathrm{SO}_{4}{ }^{2-}$ ) were determined by ion chromatograph (Dionex DX-120) using anion (AS12A/AG12) columns coupled to an self-regenerating suppressor (ASRS) in recycle mode. Concentration of major cations $\left(\mathrm{Ca}^{2+}\right.$, 
Table 1 Description of samples and sampling site

\begin{tabular}{|c|c|}
\hline Sample code & Sampling site \\
\hline \multicolumn{2}{|c|}{ River water (Sai River) } \\
\hline 1 & Pandeypur \\
\hline 2 & Pratapgarh city start \\
\hline 3 & Pratapgarh city mid \\
\hline 4 & Pratapgarh city end \\
\hline 5 & Kalapur \\
\hline 6 & Basirpur \\
\hline \multicolumn{2}{|l|}{ Pond water } \\
\hline 7 & Maharupur \\
\hline 8 & Bahadurpur \\
\hline 9 & Bhatari \\
\hline 10 & Saray Narayan \\
\hline 11 & Rampur \\
\hline 12 & Bahuta \\
\hline 13 & Rajangarh \\
\hline 14 & Chandpur \\
\hline 15 & Adharpur \\
\hline 16 & Lala Bazar \\
\hline 17 & Mangraura \\
\hline \multicolumn{2}{|l|}{ Canal water } \\
\hline 18 & Samaspur \\
\hline 19 & Sarsatpur \\
\hline 20 & Bhojemau \\
\hline 21 & Manikpur \\
\hline 22 & Lodipur \\
\hline 23 & Pratapgarh \\
\hline 24 & Savansa \\
\hline 25 & Fatehpur \\
\hline
\end{tabular}

$\mathrm{Mg}^{2+}, \mathrm{Na}^{+}$and $\mathrm{K}^{+}$) were determined by flame atomic absorption spectrophotometer (VARIAN-AA280 FS). Three replicates were run for each sample for cation analysis and the instrument was recalibrated after every 15 samples. An overall precision, expressed as percent relative standard deviation (RSD), was obtained below $10 \%$ for the entire samples. The thematic maps of water quality parameters were prepared by using ARC GIS-10.2 software.

The SPSS (version 20), a commercial statistical software package was used for computing inter-elemental correlations and principal component analysis of the database. A correlation coefficient is a commonly used measure to establish the relationship between two variables. It is simply a measure to exhibit how well one variable predicts the other. Factor analysis is a useful explanatory tool in multivariate statistical analysis, and it can be applied to discover and interpret relations among variables or to test hypotheses (Ballukraya and Ravi 1999). The common principle of the factor analysis is to find an approach of condensing the information contained in a number of original variables into a smaller set of new composite dimensions with a minimum loss of information. R-mode factor analysis was carried out with the help of SPSS software to extract the factors governing the surface water chemistry of the present study area.

\section{Results and discussion}

The physico-chemical parameters of the analysed surface water samples of the Pratapgarh district including statistical measures such as minimum, maximum, average values and standard deviation are given in Table 2.

Table 2 Summary statistics of the analytical data

\begin{tabular}{|c|c|c|c|c|c|}
\hline Water quality parameters & Units & Minimum & Maximum & Average & Standard deviation \\
\hline $\mathrm{pH}$ & - & 6.8 & 9.8 & 8.0 & 0.6 \\
\hline $\mathrm{EC}$ & $\mu \mathrm{S} \mathrm{cm}{ }^{-1}$ & 234 & 2270 & 868 & 637 \\
\hline Turbidity & NTU & 1.4 & 342 & 55 & 88 \\
\hline $\mathrm{HCO}_{3}{ }^{-}$ & $\mathrm{mg} \mathrm{L}^{-1}$ & 68 & 1290 & 320 & 265 \\
\hline $\mathrm{F}^{-}$ & $\mathrm{mg} \mathrm{L}^{-1}$ & 0.3 & 3.62 & 1.2 & 1.0 \\
\hline $\mathrm{Cl}^{-}$ & $\mathrm{mg} \mathrm{L}^{-1}$ & 2.3 & 667 & 104 & 151 \\
\hline $\mathrm{NO}_{3}^{-}$ & $\mathrm{mg} \mathrm{L}^{-1}$ & 0.8 & 69.7 & 18.3 & 19.5 \\
\hline $\mathrm{SO}_{4}{ }^{2-}$ & $\mathrm{mg} \mathrm{L}^{-1}$ & 5.9 & 103.8 & 31.5 & 23.4 \\
\hline $\mathrm{Na}^{+}$ & $\mathrm{mg} \mathrm{L}^{-1}$ & 3.3 & 320 & 75.2 & 74.2 \\
\hline $\mathrm{Ca}^{2+}$ & $\mathrm{mg} \mathrm{L}^{-1}$ & 16.8 & 96.7 & 40.1 & 21.5 \\
\hline $\mathrm{Mg}^{2+}$ & $\mathrm{mg} \mathrm{L}^{-1}$ & 8.5 & 115.5 & 28.4 & 24.2 \\
\hline $\mathrm{K}^{+}$ & $\mathrm{mg} \mathrm{L}^{-1}$ & 2.4 & 30.8 & 10.8 & 9.3 \\
\hline TDS & $\mathrm{mg} \mathrm{L}^{-1}$ & 203 & 2044 & 669 & 448 \\
\hline $\mathrm{TH}$ & $\mathrm{mg} \mathrm{L}^{-1}$ & 86 & 716 & 217 & 149 \\
\hline
\end{tabular}




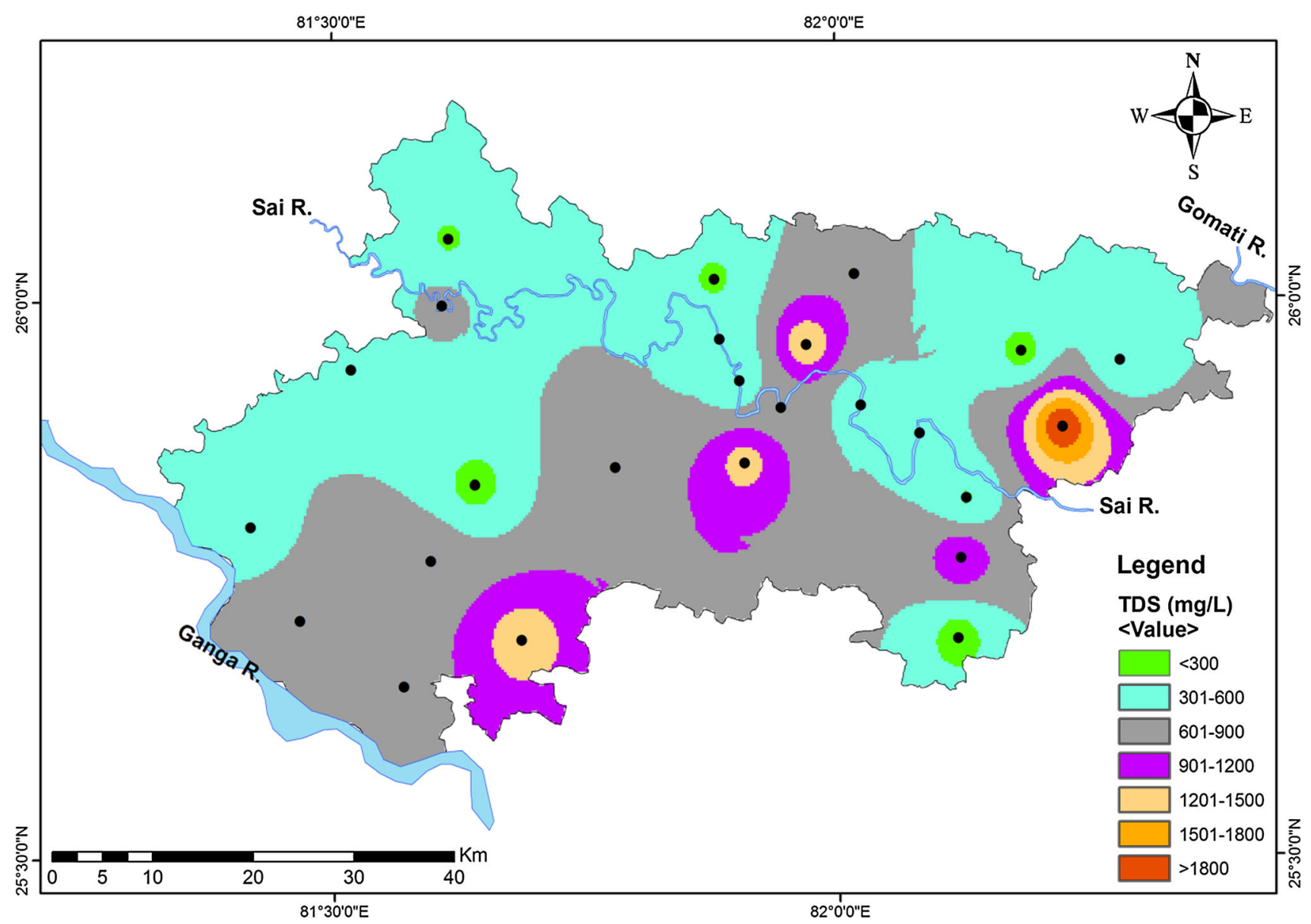

Fig. 2 Spatial distribution of total dissolved solids (TDS) concentration

\section{pH, EC and TDS}

$\mathrm{pH}$ is a measurement of the intensity of acidity or alkalinity and the concentration of $\mathrm{H}^{+}$ions in water. $\mathrm{pH}$ of the analysed water samples varied from 6.8 to 9.8 and the average $\mathrm{pH}$ was found to be 8.0 , indicating mildly acidic to alkaline nature of the surface water samples. EC denotes the conducting capacity of water, which in turn is determined by the presence of dissolved ions. EC is a measure of total dissolved solids (TDS) i.e.-it depends upon the ionic strength of the solution. Increase in the concentration of dissolved solids, increases the ionic strength of the solution. The measured EC of the surface water in the study area varies from 234 to $3270 \mu \mathrm{S} \mathrm{cm}^{-1}$ with an average value of $869 \mu \mathrm{S} \mathrm{cm}^{-1}$. Concentration of TDS in the surface water of the study area ranged from 203 to $2044 \mathrm{mg} \mathrm{L}^{-1}$ with an average value of $669 \mathrm{mg} \mathrm{L}^{-1}$. Water can be classified into fresh (TDS $<1000 \mathrm{mg} \mathrm{L}^{-1}$ ), brackish $\left(>1000 \mathrm{mg} \mathrm{L}^{-1}\right)$, saline $\left(>10,000 \mathrm{mg} \mathrm{L}^{-1}\right)$ and brine $\left(100,000 \mathrm{mg} \mathrm{L}^{-1}\right)$ categories on the basis of TDS concentration (Freeze and Cherry 1979). Based on this classification, $80 \%$ of the surface water of the study area belongs to fresh water and remaining $20 \%$ to brackish water categories. The higher standard deviations for EC $( \pm 637)$ and TDS $( \pm 478)$ values reflect wide variation in the ionic concentration in the surface water of the area. The spatial variation shows higher TDS values at sites 10, 12, 13, 14 and 23 (Fig. 2). The large spatial differences between the values of TDS could be attributed to the variation in geochemical processes and anthropogenic activities in the region. EC, TDS and ionic concentration of dissolved species are relatively higher in pond water compared to canal and river water.

\section{Major ion chemistry}

Bicarbonate, chloride, sodium and calcium are the dominant dissolved ions in the Pratapgarh surface water, constituting 51,17, 12 and $6 \%$ of the TDS, respectively, along with secondary contributions from sulphate $(5 \%)$ and magnesium $(5 \%)$. Nitrate, potassium and fluoride have very little contribution to the solute load, together account for $<4 \%$ of the TDS. The anion chemistry of surface water is dominant by $\mathrm{HCO}_{3}^{-}$and $\mathrm{Cl}^{-}$with secondary 

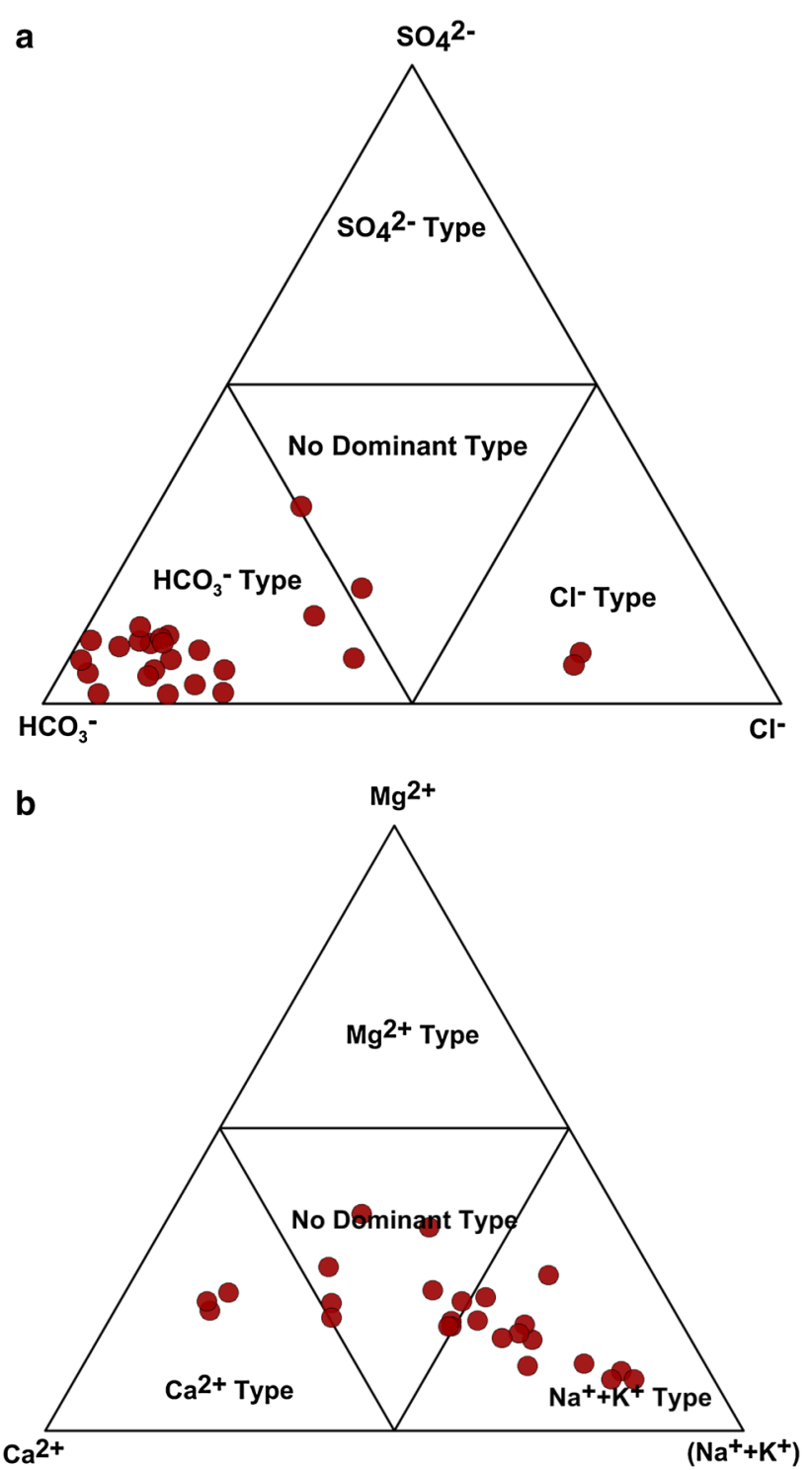

Fig. 3 Ternary a anion and $\mathbf{b}$ cation diagrams showing contribution of individual ions towards the anionic and cationic mass balance

contribution of $\mathrm{SO}_{4}{ }^{2-}$ (Fig. 3a). Nitrate and fluoride are the less dominant anions. The orders of anions abundance in the surface water were found as $\mathrm{HCO}_{3}{ }^{-}>\mathrm{Cl}^{-}>$ $\mathrm{SO}_{4}{ }^{2-}>\mathrm{NO}_{3}{ }^{-}>\mathrm{F}^{-}$. The concentration of bicarbonate varied from a minimum $68 \mathrm{mg} \mathrm{L}^{-1}$ to a maximum value of $1290 \mathrm{mg} \mathrm{L}^{-1}$ with an average value of $320 \mathrm{mg} \mathrm{L}^{-1}$. Bicarbonate is mainly derived from the soil zone by $\mathrm{CO}_{2}$ dissolution of carbonates and silicates. The soil in the subsurface environment contains elevated $\mathrm{CO}_{2}$ concentration (produced due to the decay of organic matter and root respiration), which in turn combines with rainwater to form bicarbonic acid that produces bicarbonate. The cation ternary diagram relating $\mathrm{Ca}^{2+}, \mathrm{Mg}^{2+}$ and $\mathrm{Na}^{+}, \mathrm{K}^{+}$indicates that the Pratapgarh surface water is dominated by sodium and calcium (Fig. 3b). Magnesium and potassium were the least dominant cations. The order of cation abundance is $\mathrm{Na}^{+}>\mathrm{Ca}^{2+}>\mathrm{Mg}^{2+}>\mathrm{K}^{+}$in the surface water of the area.

\section{Hydrogeochemical facies of surface water}

The Piper (1944) diagram is very useful in determining relationships of different dissolved constituents and classification of water on the basis of its chemical characters. The triangular cationic field of Piper diagram reveals that $48 \%$ of the surface water samples fall into $(\mathrm{Na}+\mathrm{K})$ dominant class and $40 \%$ into no dominance class, whereas in anionic triangle, majority of the samples (84\%) fall into bicarbonate field. About $8 \%$ of the surface water samples fall into chloride field and $8 \%$ into no dominant field of anion triangle (Fig. 4). The plot of chemical data on diamond-shaped central field, which relates the cation and anion triangles reveals that plotted points fall in the 1, 2, 3, 4, 5, 7 and 9 fields. In majority of the surface water samples, alkaline earth metals $\left(\mathrm{Ca}^{2+}+\mathrm{Mg}^{2+}\right)$ exceed alkali metal cations $\left(\mathrm{Na}^{+}+\mathrm{K}^{+}\right)$ and plotted points fall in the field 1 . About $84 \%$ surface water samples exhibit dominance of $\mathrm{HCO}_{3}{ }^{-}$over $\left(\mathrm{SO}_{4}{ }^{2-}+\mathrm{Cl}^{-}\right)$and plotted points fall in the field 3. The plotted points of $60 \%$ surface water samples fall in the field 5 suggesting carbonate hardness, while one sample $(4 \%)$ in the field 6 and two samples $(8 \%)$ in the field 7 , indicate non-carbonate hardness. About $24 \%$ surface water samples fall in the field 9, which indicate an intermediate chemical character of surface water having none of the cation-anion pairs dominants in the chemical composition. $\mathrm{Ca}^{2+}-\mathrm{Mg}^{2+}-\mathrm{HCO}_{3}{ }^{-}$is the dominant hydrogeochemical facies in $60 \%$ of the surface water samples, while $24 \%$ surface water samples occur as a mixed chemical character of $\mathrm{Ca}^{2+}-\mathrm{Mg}^{2+}-\mathrm{Cl}^{-}$and $\mathrm{Na}^{+}-\mathrm{HCO}_{3}{ }^{-}-\mathrm{Cl}^{-}$hydrogeochemical facies.

\section{Statistical analysis}

Statistical analysis is an important tool used to process large amounts of data and report overall trends. This analysis attempts to establish the nature of the relationship between the water quality parameters and WQI. The computed correlation matrix of the 16 measured parameters is given in Table 3. EC and TDS show high positive correlation with $\mathrm{Na}^{+}, \mathrm{K}^{+}, \mathrm{Cl}^{-}$and $\mathrm{HCO}_{3}{ }^{-}$and moderate correlation with $\mathrm{Ca}^{2+}, \mathrm{Mg}^{2+}, \mathrm{SO}_{4}{ }^{2-}$ and total hardness (TH). There is good correlation between $\mathrm{Ca}^{2+}$ and $\mathrm{Mg}^{2+}$ $(0.88), \mathrm{Na}^{+}$and $\mathrm{K}^{+}(0.74)$ and moderate correlation of $\mathrm{HCO}_{3}{ }^{-}-\mathrm{Na}^{+}(0.48)$. Good correlations were also observed between $\mathrm{Ca}^{2+}-\mathrm{Cl}^{-}$(0.82), $\mathrm{Mg}^{2+}-\mathrm{Cl}^{-}$(0.85), $\mathrm{Ca}^{2+}-\mathrm{TH}$ (0.90) and $\mathrm{Mg}^{2+}-\mathrm{TH}(0.95)$, indicating similar source and/ or geochemical behaviour during various processes. The 

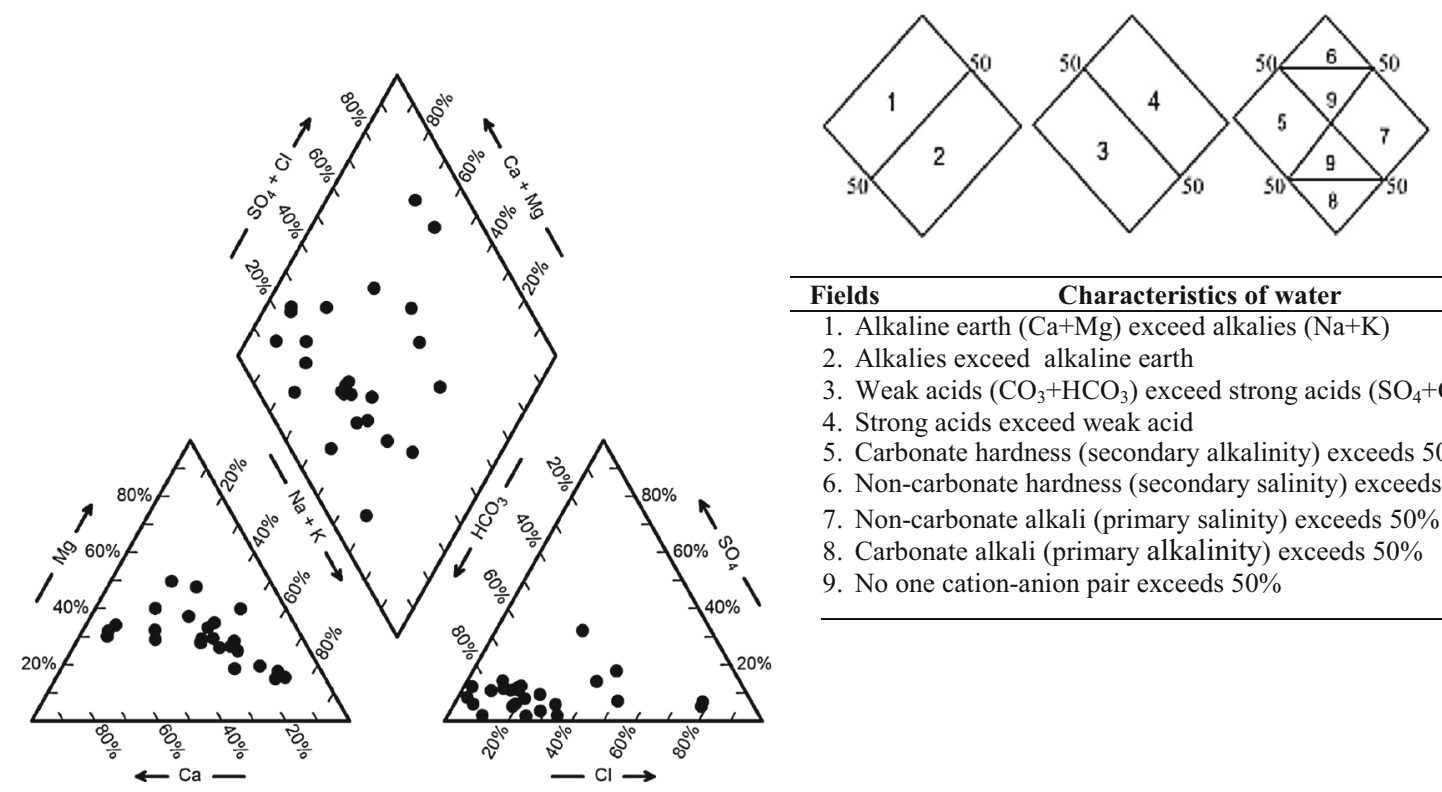

\begin{tabular}{l} 
Fields Characteristics of water \\
\hline 1. Alkaline earth $(\mathrm{Ca}+\mathrm{Mg})$ exceed alkalies $(\mathrm{Na}+\mathrm{K})$ \\
2. Alkalies exceed alkaline earth \\
3. Weak acids $\left(\mathrm{CO}_{3}+\mathrm{HCO}_{3}\right)$ exceed strong acids $\left(\mathrm{SO}_{4}+\mathrm{Cl}\right)$ \\
4. Strong acids exceed weak acid \\
5. Carbonate hardness (secondary alkalinity) exceeds $50 \%$ \\
6. Non-carbonate hardness (secondary salinity) exceeds $50 \%$ \\
7. Non-carbonate alkali (primary salinity) exceeds $50 \%$ \\
8. Carbonate alkali (primary alkalinity) exceeds $50 \%$ \\
9. No one cation-anion pair exceeds $50 \%$
\end{tabular}

Fig. 4 Piper trilinear diagram showing hydrogeochemical character of surface water

Table 3 Correlation coefficient matrix of water quality parameters and WQI

\begin{tabular}{|c|c|c|c|c|c|c|c|c|c|c|c|c|c|c|c|c|}
\hline Parameters & $\mathrm{pH}$ & $\mathrm{EC}$ & TDS & Turb. & $\mathrm{F}^{-}$ & $\mathrm{Cl}^{-}$ & $\mathrm{NO}_{3}^{-}$ & $\mathrm{SO}_{4}^{2-}$ & $\mathrm{HCO}_{3}{ }^{-}$ & Silica & $\mathrm{Ca}^{2+}$ & $\mathrm{Mg}^{2+}$ & $\mathrm{Na}^{+}$ & $\mathrm{K}^{+}$ & $\mathrm{TH}$ & WQI \\
\hline $\mathrm{pH}$ & 1.00 & & & & & & & & & & & & & & & \\
\hline $\mathrm{EC}$ & 0.70 & 1.00 & & & & & & & & & & & & & & \\
\hline TDS & 0.77 & 0.97 & 1.00 & & & & & & & & & & & & & \\
\hline Turb. & -0.15 & -0.03 & 0.08 & 1.00 & & & & & & & & & & & & \\
\hline $\mathrm{F}^{-}$ & 0.71 & 0.60 & 0.66 & 0.09 & 1.00 & & & & & & & & & & & \\
\hline $\mathrm{Cl}^{-}$ & 0.13 & 0.70 & 0.57 & -0.18 & 0.12 & 1.00 & & & & & & & & & & \\
\hline $\mathrm{NO}_{3}{ }^{-}$ & 0.13 & 0.36 & 0.34 & -0.07 & 0.28 & 0.20 & 1.00 & & & & & & & & & \\
\hline $\mathrm{SO}_{4}{ }^{2-}$ & 0.31 & 0.63 & 0.56 & 0.22 & 0.41 & 0.51 & 0.20 & 1.00 & & & & & & & & \\
\hline $\mathrm{HCO}_{3}{ }^{-}$ & 0.86 & 0.73 & 0.86 & 0.17 & 0.70 & 0.08 & 0.24 & 0.29 & 1.00 & & & & & & & \\
\hline Silica & 0.55 & 0.58 & 0.60 & -0.02 & 0.14 & 0.31 & 0.11 & 0.28 & 0.54 & 1.00 & & & & & & \\
\hline $\mathrm{Ca}^{2+}$ & 0.12 & 0.59 & 0.48 & -0.29 & -0.05 & 0.83 & 0.34 & 0.31 & 0.08 & 0.47 & 1.00 & & & & & \\
\hline $\mathrm{Mg}^{2+}$ & 0.17 & 0.63 & 0.54 & -0.29 & 0.01 & 0.86 & 0.29 & 0.22 & 0.17 & 0.49 & 0.88 & 1.00 & & & & \\
\hline $\mathrm{Na}^{+}$ & 0.50 & 0.78 & 0.73 & -0.18 & 0.62 & 0.62 & 0.45 & 0.50 & 0.47 & 0.19 & 0.51 & 0.45 & 1.00 & & & \\
\hline $\mathrm{K}^{+}$ & 0.46 & 0.64 & 0.62 & -0.09 & 0.67 & 0.32 & 0.76 & 0.49 & 0.52 & 0.09 & 0.36 & 0.27 & 0.74 & 1.00 & & \\
\hline $\mathrm{TH}$ & 0.14 & 0.59 & 0.49 & -0.30 & -0.04 & 0.86 & 0.29 & 0.23 & 0.10 & 0.43 & 0.90 & 0.95 & 0.44 & 0.29 & 1.00 & \\
\hline WQI & 0.66 & 0.95 & 0.94 & -0.06 & 0.69 & 0.70 & 0.50 & 0.58 & 0.69 & 0.49 & 0.61 & 0.66 & 0.83 & 0.75 & 0.62 & 1.00 \\
\hline
\end{tabular}

positive correlation between $\mathrm{Cl}^{-}$and $\mathrm{Na}^{+}(0.62), \mathrm{Cl}^{-}$and TDS (0.57) and $\mathrm{Na}^{+}$and TDS (0.73) indicate that $\mathrm{Cl}^{-}$and part of the $\mathrm{Na}^{+}$are derived from anthropogenic sources. The observed higher $\mathrm{Na}^{+} / \mathrm{Cl}^{-}$ratio (avg. 1.8) in the surface water as compared with marine aerosols $\left(\mathrm{Na}^{+} /\right.$ $\mathrm{Cl}^{-}=0.85$ ), suggests limited contribution from atmospheric precipitation and reveals that major ions are manly derived from weathering of rock forming minerals and anthropogenic sources. The poor correlation of $\mathrm{Ca}^{2+}$ with $\mathrm{SO}_{4}{ }^{2-}(0.30)$ indicates that gypsum dissolution could not be the major contributor for the dissolved ions in the water of study area. Further, a relatively high $\left(\mathrm{Na}^{+}+\mathrm{K}^{+}\right) / \mathrm{TZ}^{+}$i.e. 0.39 and low $\left(\mathrm{Ca}^{2+}+\mathrm{Mg}^{2+}\right) /\left(\mathrm{Na}^{+}+\mathrm{K}^{+}\right)$i.e. 2.7 ratios suggest that the silicate weathering is largely controlled chemical composition of surface water with limited contribution by carbonate dissolution. Computed WQI show significant correlation with the TDS $(0.94), \mathrm{Na}^{+}(0.83), \mathrm{K}^{+}$ (0.75), $\mathrm{Cl}^{-}$(0.70), $\mathrm{F}^{-}(0.69), \mathrm{HCO}_{3}^{-}(0.69), \mathrm{Mg}^{2+}(0.66)$ and moderately correlated with $\mathrm{TH}(0.62), \mathrm{Ca}^{2+}(0.60)$, $\mathrm{SO}_{4}{ }^{2-}(0.57)$ and $\mathrm{NO}_{3}{ }^{-}(0.49)$. 
Table 4 Principal and R-mode varimax rotated factor loading of surface water parameters

\begin{tabular}{|c|c|c|c|c|c|c|c|}
\hline \multirow[t]{2}{*}{ Variables } & \multicolumn{3}{|c|}{ Principal factor matrix } & \multirow[t]{2}{*}{ Communality } & \multicolumn{3}{|c|}{ Varimax rotated factor matrix } \\
\hline & PC-I & PC-II & PC-III & & PC-I & PC-II & PC-III \\
\hline $\mathrm{pH}$ & 0.712 & -0.505 & -0.340 & 0.878 & 0.878 & 0.025 & 0.169 \\
\hline $\mathrm{EC}$ & 0.974 & 0.025 & -0.110 & 0.962 & 0.962 & 0.562 & 0.414 \\
\hline TDS & 0.957 & -0.128 & -0.176 & 0.963 & 0.963 & 0.438 & 0.373 \\
\hline $\mathrm{F}^{-}$ & 0.656 & -0.610 & 0.166 & 0.830 & 0.830 & -0.181 & 0.580 \\
\hline $\mathrm{Cl}^{-}$ & 0.671 & 0.655 & 0.027 & 0.880 & 0.880 & 0.896 & 0.268 \\
\hline $\mathrm{HCO}_{3}^{-}$ & 0.729 & -0.543 & -0.290 & 0.910 & 0.910 & -0.006 & 0.226 \\
\hline $\mathrm{SO}_{4}{ }^{2-}$ & 0.618 & 0.016 & 0.132 & 0.400 & 0.400 & 0.322 & 0.431 \\
\hline $\mathrm{NO}_{3}{ }^{-}$ & 0.483 & 0.029 & 0.610 & 0.607 & 0.607 & 0.175 & 0.759 \\
\hline Silica & 0.568 & 0.103 & -0.651 & 0.758 & 0.758 & 0.505 & -0.264 \\
\hline $\mathrm{Ca}^{2+}$ & 0.618 & 0.322 & -0.014 & 0.904 & 0.904 & 0.330 & 0.196 \\
\hline $\mathrm{Mg}^{2+}$ & 0.632 & 0.386 & -0.135 & 0.889 & 0.889 & 0.329 & 0.107 \\
\hline $\mathrm{Na}^{+}$ & 0.830 & 0.006 & 0.320 & 0.791 & 0.791 & 0.394 & 0.701 \\
\hline \multirow[t]{4}{*}{$\mathrm{K}^{+}$} & 0.747 & -0.206 & 0.568 & 0.924 & 0.924 & 0.130 & 0.899 \\
\hline & & & \multicolumn{2}{|c|}{ Eigen values } & 6.75 & 2.41 & 1.53 \\
\hline & & & \multicolumn{2}{|c|}{ Variance percent } & 51.94 & 18.57 & 11.75 \\
\hline & & & \multicolumn{2}{|c|}{ Cumulative percent } & 51.94 & 70.51 & 82.26 \\
\hline
\end{tabular}

Table 5 Surface water samples of the study area exceeding the maximum desirable limits prescribed by WHO and Indian Standard (IS: 10500) for domestic purposes

\begin{tabular}{|c|c|c|c|c|c|c|}
\hline \multirow{2}{*}{$\begin{array}{l}\text { Water quality } \\
\text { parameters }\end{array}$} & \multicolumn{2}{|l|}{ WHO (1997) } & \multicolumn{2}{|c|}{ BIS (2003) (IS 10500) } & \multirow{2}{*}{$\begin{array}{l}\text { Number of samples exceeding } \\
\text { max. desirable limits }\end{array}$} & \multirow{2}{*}{$\begin{array}{l}\text { Percentage of samples exceeding } \\
\text { max. desirable limits }\end{array}$} \\
\hline & $\begin{array}{l}\text { Highest } \\
\text { permissible } \\
\text { limits }\end{array}$ & $\begin{array}{l}\text { Max. } \\
\text { desirable }\end{array}$ & $\begin{array}{l}\text { Highest } \\
\text { permissible } \\
\text { limits }\end{array}$ & $\begin{array}{l}\text { Max. } \\
\text { desirable }\end{array}$ & & \\
\hline $\mathrm{pH}$ & $6.5-9.2$ & $7.0-8.5$ & $8.5-9.2$ & $6.5-8.5$ & 2 & 8 \\
\hline $\mathrm{EC}$ & 1,500 & 750 & - & - & 13 & 52 \\
\hline Turbidity & - & $<5.0$ & 5.0 & 1.0 & 19 & 76 \\
\hline $\mathrm{HCO}_{3}{ }^{-}$ & 600 & 200 & 600 & 200 & 14 & 56 \\
\hline $\mathrm{F}^{-}$ & 1.5 & $0.6-0.9$ & 1.5 & 1.0 & 9 & 36 \\
\hline $\mathrm{Cl}^{-}$ & 600 & 250 & 1000 & 250 & 3 & 12 \\
\hline $\mathrm{NO}_{3}^{-}$ & 50 & - & 100 & 45 & 3 & 12 \\
\hline $\mathrm{SO}_{4}{ }^{2-}$ & 600 & 200 & 400 & 200 & Nil & Nil \\
\hline $\mathrm{Na}^{+}$ & 200 & 50 & - & - & 12 & 48 \\
\hline $\mathrm{Ca}^{2+}$ & 200 & 75 & 200 & 75 & 3 & 12 \\
\hline $\mathrm{Mg}^{2+}$ & 150 & 30 & 100 & 30 & 9 & 36 \\
\hline $\mathrm{K}^{+}$ & 200 & 100 & - & - & Nil & Nil \\
\hline TDS & 1,500 & 500 & 2000 & 500 & 13 & 52 \\
\hline $\mathrm{TH}$ & 500 & 100 & 600 & 300 & 4 & 16 \\
\hline
\end{tabular}

All concentration in $\mathrm{mg} \mathrm{L}^{-1}$, except $\mathrm{pH}, \mathrm{EC}\left(\mu \mathrm{S} \mathrm{cm}^{-1}\right)$, Turbidity (NTU)

The data matrix of 13 variables (pH, EC, TDS, $\mathrm{F}^{-}, \mathrm{Cl}^{-}$, $\mathrm{SO}_{4}{ }^{2-}, \mathrm{NO}_{3}{ }^{-}, \mathrm{HCO}_{3}{ }^{-}$, silica, $\mathrm{Ca}^{2+}, \mathrm{Mg}^{2+}, \mathrm{Na}^{+}, \mathrm{K}^{+}$) of twenty-five water samples were used for factor analysis. Three factors with eigen values $>1$ have been extracted from the principal factor matrix after varimax rotation. Factor loading, communalities for each variables, eigen values, percentage of variance and cumulative percent for three extracted factors are given in Table 4 . The three extracted factors explain 52,19 and $12 \%$ of total variance, respectively, in the data matrix for the surface water of Pratapgarh. Factor-I contributes $52 \%$ of the total variance and shows strong loading of $\mathrm{pH}, \mathrm{EC}, \mathrm{TDS}, \mathrm{Ca}^{2+}, \mathrm{Mg}^{2+}$, 


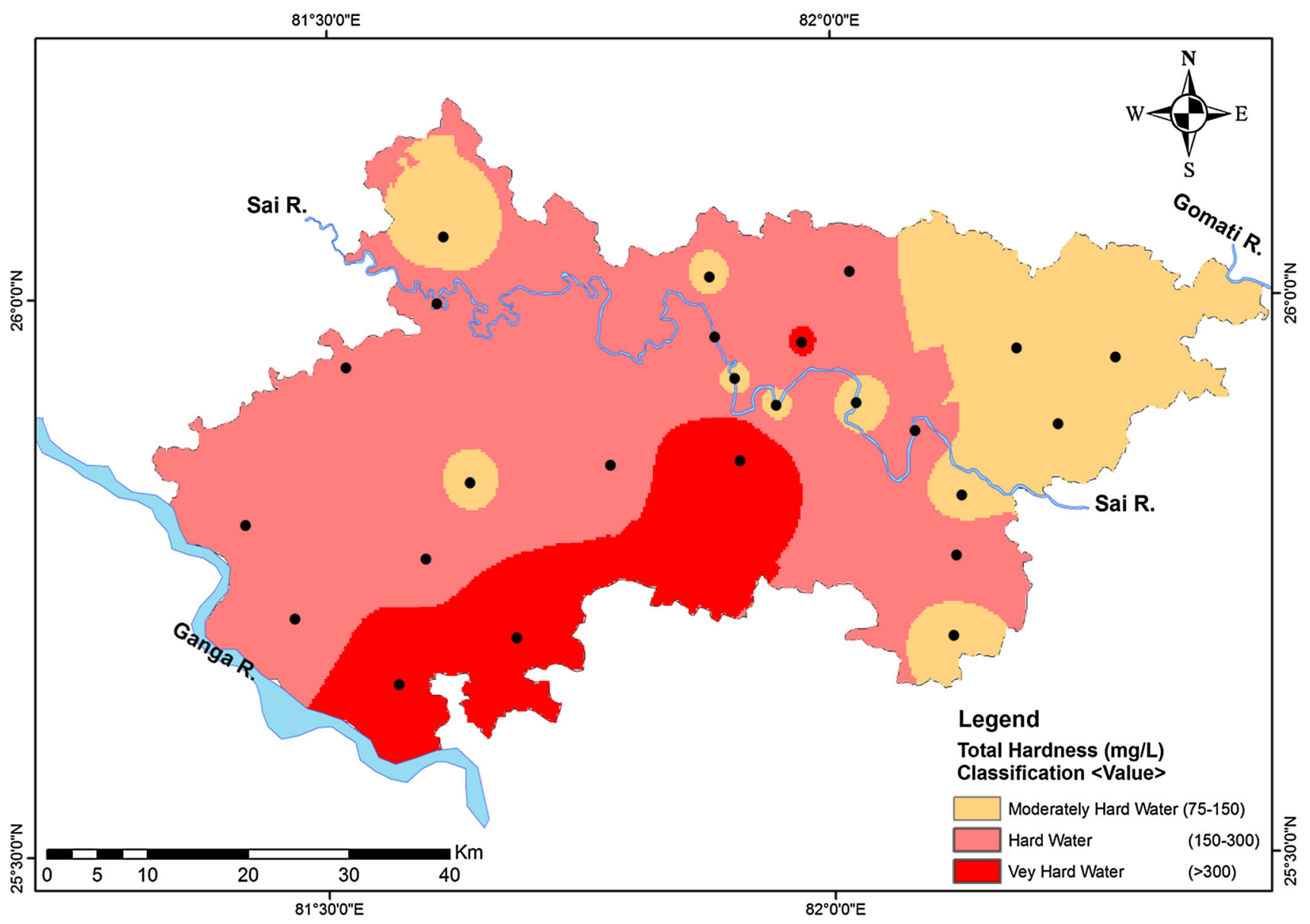

Fig. 5 Spatial distribution for total hardness (TH) in Pratapgarh district surface water

$\mathrm{Na}^{+}, \mathrm{K}^{+}$, silica, $\mathrm{SO}_{4}{ }^{2-}$ and $\mathrm{HCO}_{3}{ }^{-}$. Factor-I in the surface water is explicitly a lithogenic factor, which explains the dissolution of silicates with limited contribution from bicarbonate weathering. The second rotated factor (PC-II) accounts for $18.6 \%$ of the variance and shows high loading of $\mathrm{Cl}^{-}$and low loading of $\mathrm{Ca}^{2+}$ and $\mathrm{Mg}^{2+}$, may be attributed to anthropogenic activities. Factor PC-III is less significant, accounts for only $12 \%$ of the total variance and shows high loading of $\mathrm{NO}_{3}{ }^{-}$and $\mathrm{K}^{+}$and less loading of $\mathrm{Na}^{+}$. This factor may be attributed to the anthropogenic activities such as domestic and run off from the agricultural field. These three factors explain about $82 \%$ of the total variance in the data matrix, indicating that the determined variables, which control the surface water chemistry of the area by silicate weathering with minor contribution from anthropogenic sources.

\section{Surface water quality assessment}

The data obtained by hydrogeochemical analyses of twenty-five surface water samples of Pratapgarh district were evaluated in terms of its suitability for drinking and domestic uses.

\section{Potability of surface water for drinking and domestic uses}

The physical and chemical parameters of the analytical results of surface water were compared with the standard guideline values recommended by the World Health Organisation (WHO 1997) and Bureau of Indian Standards (BIS 2003) for drinking and public health (Table 5). The $\mathrm{pH}$ of the surface water samples (6.8-9.8) are within the safe limit of 6.5-8.5, prescribed for drinking water except at sites 12 and 14 . The turbidity is one of the important physical parameters for water quality, defining the presence of suspended solids in water and causes the muddy or turbid appearance of water body. The consumption of high turbid water may cause a health risk as excessive turbidity can protect pathogenic microorganisms from effects of disinfectants and stimulate the growth of bacteria during storage (Singh et al. 2013c; 


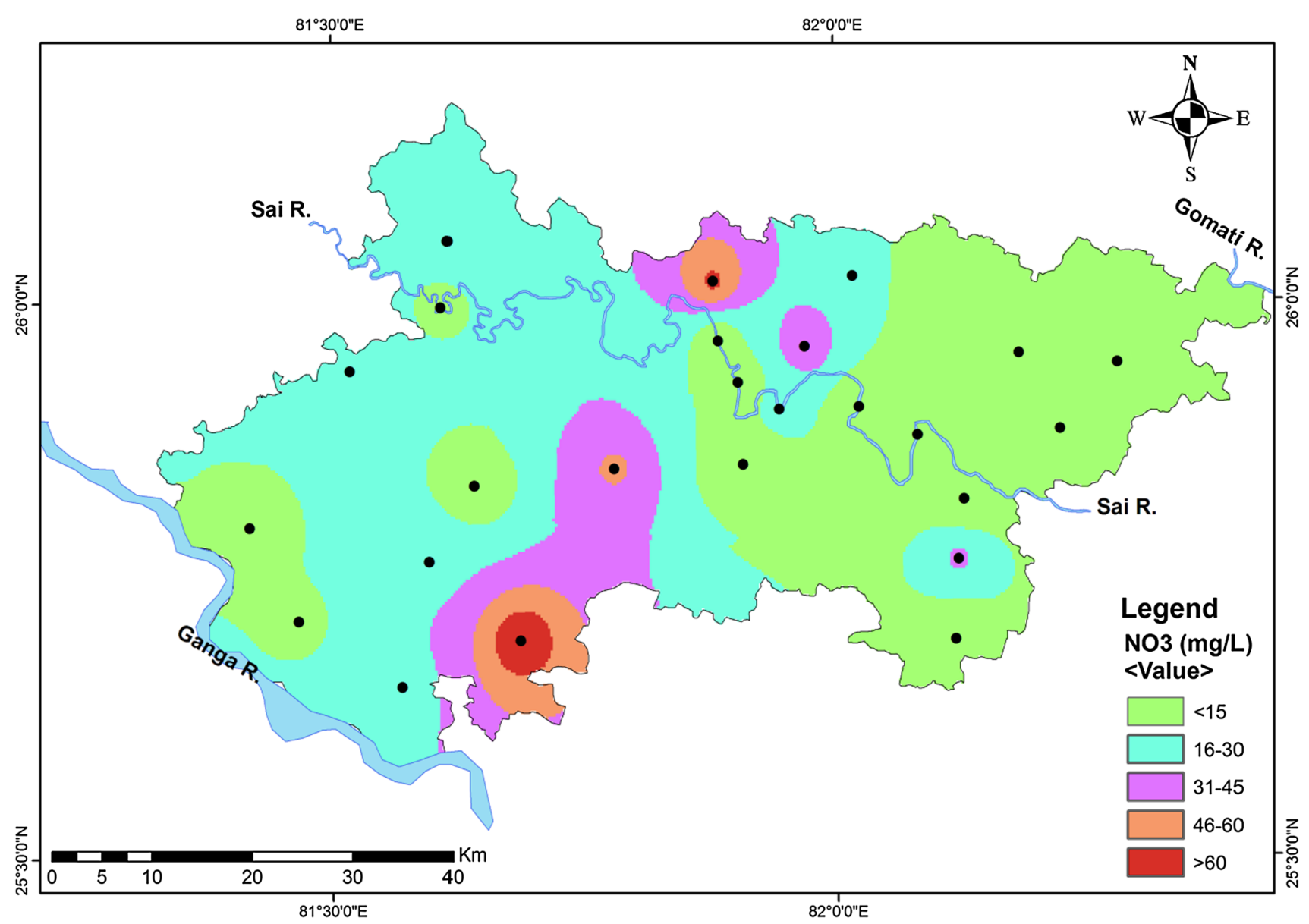

Fig. 6 Spatial distribution of nitrate concentration in Pratapgarh district surface water

Tiwari and Singh 2014). In the present study area, the turbidity ranges from 1.4 to $342 \mathrm{NTU}$ and exceeds the recommended value of $5 \mathrm{NTU}$ in $76 \%$ of surface water samples. The values of TDS exceed the desirable limit of $500 \mathrm{mg} \mathrm{L}^{-1}$ in $52 \%$ analysed samples and maximum permissible limit of $1,000 \mathrm{mg} \mathrm{L}^{-1}$ in $20 \%$ water samples of Pratapgarh district. The total hardness (TH) is an important parameter of water quality whether it is to be used for domestic, industrial or agricultural purposes. Hardness of the water is the property attributed to the presence of alkaline earths. It is property of water by which it prevents the lather formation with soap and increases the boiling point of water. Water can be classified into soft $\left(75 \mathrm{mg} \mathrm{L}^{-1}\right)$, moderately hard $(75-150 \mathrm{mg}$ $\left.\mathrm{L}^{-1}\right)$, hard $\left(150-300 \mathrm{mg} \mathrm{L}^{-1}\right)$ and very hard $(>300 \mathrm{mg}$ $\mathrm{L}^{-1}$ ) based on hardness (Sawyer and McCarty 1967). The $\mathrm{TH}$ of the analysed surface water of the study area varies between 86 and $716 \mathrm{mg} \mathrm{L}^{-1}$ (avg. $217 \mathrm{mg} \mathrm{L}^{-1}$ ) indicating moderately hard to very hard type of surface water. The analytical data indicate that $48 \%$ surface water samples are moderately hard and $36 \%$ are of hard categories, while $16 \%$ water samples have hardness higher than $300 \mathrm{mg} \mathrm{L}^{-1}$, which is the desirable limit for drinking purposes (Fig. 5). The high hardness may cause encrustation on water supply distribution systems. Long-term consumption of extremely hard water might lead to an increased incidence of urolithiasis, anencephaly, prenatal mortality, some types of cancer and cardio-vascular disorders (Agrawal and Jagetia 1997). Fluoride is an essential element for maintaining normal development of teeth and bones. Concentration of $\mathrm{F}^{-}$exceeds the permissible limit of $1.5 \mathrm{mg} \mathrm{L}^{-1}$ in about $16 \%$ water samples. Higher concentration of fluoride causes dental and skeletal fluorosis such as mottling of teeth, deformation of ligaments and bending of spinal chord (Tiwari and Singh 2014). Concentration of $\mathrm{NO}_{3}{ }^{-}$is higher than the recommended level of $45 \mathrm{mg} \mathrm{L}^{-1}$ in $12 \%$ of the surface water samples (Fig. 6). Excessive $\mathrm{NO}_{3}{ }^{-}$in drinking water can cause a number of disorders including methemoglobinemia in infants, gastric cancer, goitre, birth malformations and hypertensions (Majumdar and Gupta 2000). Concentrations of $\mathrm{Cl}^{-}$exceeds desirable limit of $250 \mathrm{mg} \mathrm{L}^{-1}$ in 


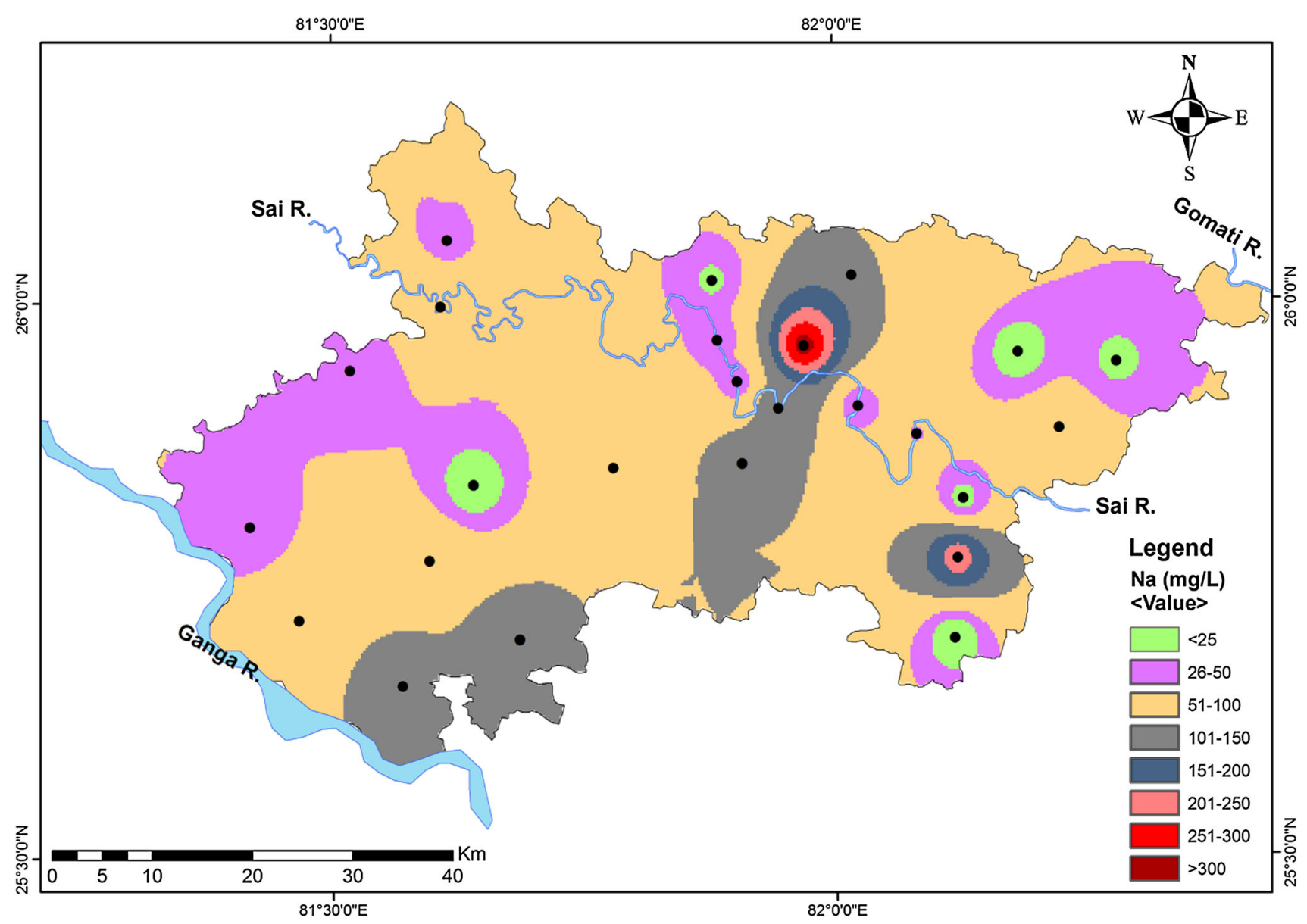

Fig. 7 Spatial distribution of sodium concentration in Pratapgarh district surface water

Table 6 Relative weights of chemical parameters

\begin{tabular}{llll}
\hline $\begin{array}{l}\text { Chemical } \\
\text { parameters }\end{array}$ & $\begin{array}{l}\text { Standards (BIS/ } \\
\text { WHO) }\end{array}$ & $\begin{array}{l}\text { Weight } \\
\left(w_{\mathrm{i}}\right)\end{array}$ & $\begin{array}{l}\text { Relative weight } \\
\left(W_{\mathrm{i}}\right)\end{array}$ \\
\hline $\mathrm{pH}$ & 8.5 & 4 & 0.089 \\
$\begin{array}{l}\text { Total dissolved } \\
\text { solids }\end{array}$ & 500 & 5 & 0.111 \\
Fluoride & 1 & 5 & 0.111 \\
Chloride & 250 & 5 & 0.111 \\
Nitrate & 45 & 5 & 0.111 \\
Sulphate & 200 & 5 & 0.111 \\
Bicarbonate & 200 & 1 & 0.022 \\
Calcium & 75 & 3 & 0.067 \\
Magnesium & 30 & 3 & 0.067 \\
Sodium & 50 & 5 & 0.111 \\
Potassium & 100 & 2 & 0.044 \\
Total hardness & 300 & 2 & 0.044 \\
& & $\Sigma \mathrm{w}_{\mathrm{i}}=45$ & $\Sigma \mathrm{W}_{\mathrm{i}}=1.00$ \\
\hline
\end{tabular}

All concentrations are in $\mathrm{mg} \mathrm{L}^{-1}$, except $\mathrm{pH}$
Table 7 Classification of WQI range and category of water

\begin{tabular}{ll}
\hline WQI range & Category of water \\
\hline$<50$ & Excellent water \\
$50-100$ & Good water \\
$100-200$ & Poor water \\
$200-300$ & Very poor water \\
$>300$ & Unfit for drinking purpose
\end{tabular}

about $12 \%$ surface water samples of the Pratapgarh district. Concentrations of $\mathrm{SO}_{4}{ }^{2-}$ are well within the desirable limit of $200 \mathrm{mg} \mathrm{L}^{-1}$.

Sodium and potassium are the most important elements occurring naturally and mainly derived from weathering of rocks besides the sewage and industrial effluents (Singh and Hasnain 1999). A higher sodium intake may cause hypertension, congenial heart diseases and kidney problems (Singh et al. 2008) and the excess amount of potassium present in the water sample may lead nervous and 
Table 8 Water Quality Index (WRI) value of surface water of Pratapgarh district

\begin{tabular}{|c|c|c|}
\hline Sample code & WQI & Description \\
\hline 1 & 43 & Excellent \\
\hline 2 & 39 & Excellent \\
\hline 3 & 97 & Good \\
\hline 4 & 40 & Excellent \\
\hline 5 & 80 & Good \\
\hline 6 & 50 & Excellent \\
\hline 7 & 92 & Good \\
\hline 8 & 119 & Poor \\
\hline 9 & 61 & Good \\
\hline 10 & 152 & Poor \\
\hline 11 & 100 & Good \\
\hline 12 & 146 & Poor \\
\hline 13 & 146 & Poor \\
\hline 14 & 160 & Poor \\
\hline 15 & 52 & Good \\
\hline 16 & 60 & Good \\
\hline 17 & 90 & Good \\
\hline 18 & 47 & Excellent \\
\hline 19 & 28 & Excellent \\
\hline 20 & 38 & Excellent \\
\hline 21 & 121 & Poor \\
\hline 22 & 28 & Excellent \\
\hline 23 & 198 & Poor \\
\hline 24 & 31 & Excellent \\
\hline 25 & 40 & Excellent \\
\hline
\end{tabular}

digestive disorder (Tiwary 2001). The recommended permissible limit for sodium concentration in drinking water is $200 \mathrm{mg} \mathrm{L}^{-1}$ (WHO 1997). Concentration of $\mathrm{Na}^{+}$is well within the recommended limit in surface water samples except at sites 14 and 23 (Fig. 7). Calcium and magnesium are the essential nutrients for plant growth and animals and play an important role in the development of bone, nervous system and cell. One possible adverse effect from ingesting high concentration of $\mathrm{Ca}^{2+}$ for long periods may be an increased risk of kidney stones (Maragella et al. 1996). Concentration of $\mathrm{Ca}^{2+}$ and $\mathrm{Mg}^{2+}$ are exceeding the desirable limits of $75 \mathrm{mg} \mathrm{L}^{-1}$ and $30 \mathrm{mg} \mathrm{L}^{-1}$ in $12 \%$ and $36 \%$ of the surface water samples, respectively. However, concentrations of $\mathrm{Ca}^{2+}$ and $\mathrm{Mg}^{2+}$ ions are within the maximum permissible limit of $200 \mathrm{mg} \mathrm{L}^{-1}$ and $100 \mathrm{mg}$ $\mathrm{L}^{-1}$, respectively, except for $\mathrm{Mg}^{2+}$ at site 10 . The presence of calcium and magnesium make the water hard.

\section{Evaluation of water quality index}

WQI is an important way to assess the quality of water in the recent years due to its usefulness for the understanding of water quality issues by integrating complex data (Tiwari and Mishra 1985; Singh 1992; Rao 1997; Mishra and Patel 2001). For computing WQI, three steps are followed. In the first step, each of the 12 parameters $\left(\mathrm{pH}, \mathrm{TDS}, \mathrm{F}^{-}, \mathrm{Cl}^{-}\right.$, $\mathrm{NO}_{3}^{-}, \mathrm{SO}_{4}^{2-}, \mathrm{HCO}_{3}^{-}, \mathrm{Ca}^{2+}, \mathrm{Mg}^{2+}, \mathrm{Na}^{+}, \mathrm{K}^{+}$and $\left.\mathrm{TH}\right)$ has been assigned a weight $\left(w_{i}\right)$ according to its relative importance in the overall quality of water for drinking purposes (Table 6). WQI is computed by adopting the following formula (Vasanthavigar et al. 2010; Tiwari et al. 2014).

The maximum weight of 5 has been assigned to the parameters like TDS, $\mathrm{Na}^{+}, \mathrm{F}^{-}, \mathrm{Cl}^{-}, \mathrm{NO}_{3}^{-}$and $\mathrm{SO}_{4}^{2-}$ due to their major importance in water quality assessment (Vasanthavigar et al. 2010; Tiwari et al. 2014). $\mathrm{HCO}_{3}{ }^{-}$is given the minimum weight of 1 as it plays an insignificant role in the water quality assessment. Other parameters like $\mathrm{pH}$, $\mathrm{Ca}^{2+}, \mathrm{Mg}^{2+}, \mathrm{K}^{+}$and $\mathrm{TH}$ were assigned weight $\left(w_{i}\right)$ between 2 and 5 depending on their importance in water quality determination. In the second step, the relative weight $\left(W_{i}\right)$ is computed from the following equation:

$W_{i}=w_{i} / \sum_{i=1}^{n} w_{i}$

where, $W_{i}$ is the relative weight, $w_{i}$ is the weight of each parameter and $n$ is the number of parameters. Calculated relative weight $\left(W_{\underline{i}}\right)$ values of each parameter are given in (Table 6).

In the third step, a quality rating scale $\left(q_{\mathrm{i}}\right)$ for each parameter is assigned by dividing its concentration in each water sample by its respective standard according to the guidelines laid down in the BIS 10500 (2003) and WHO (1997), and the result is multiplied by 100 :

$q_{i}=\left(C_{i} / S_{i}\right) \times 100$,

where, $q_{i}$ the is the quality rating, $C_{i}$ is the concentration of each chemical parameter in each water sample in $\mathrm{mg} \mathrm{L}^{-1}$ and $S_{i}$ is the BIS standard for each chemical parameter in $\mathrm{mg} \mathrm{L}^{-1}$ according to the guidelines of the BIS 10500 (2003) and WHO (1997).

For computing the WQI, the SI is first determined for each chemical parameter, which is then used to determine the WQI as per the following equation

$\mathrm{SI}=W_{i} \times q_{i}$

$\mathrm{WQI}=\sum \mathrm{SI}_{i}$,

where, the $\mathrm{SI}_{i}$ is the sub-index of $i$ th parameter, $q_{i}$ is the rating based on concentration of $i$ th parameter and $n$ is the number of parameters.

Water can be classified into five categories based on the WQI value (Table 7). The computed WQI value in the Pratapgarh district of surface water ranges from 28 to 198 with an average value of 82 . The highest WQI were 


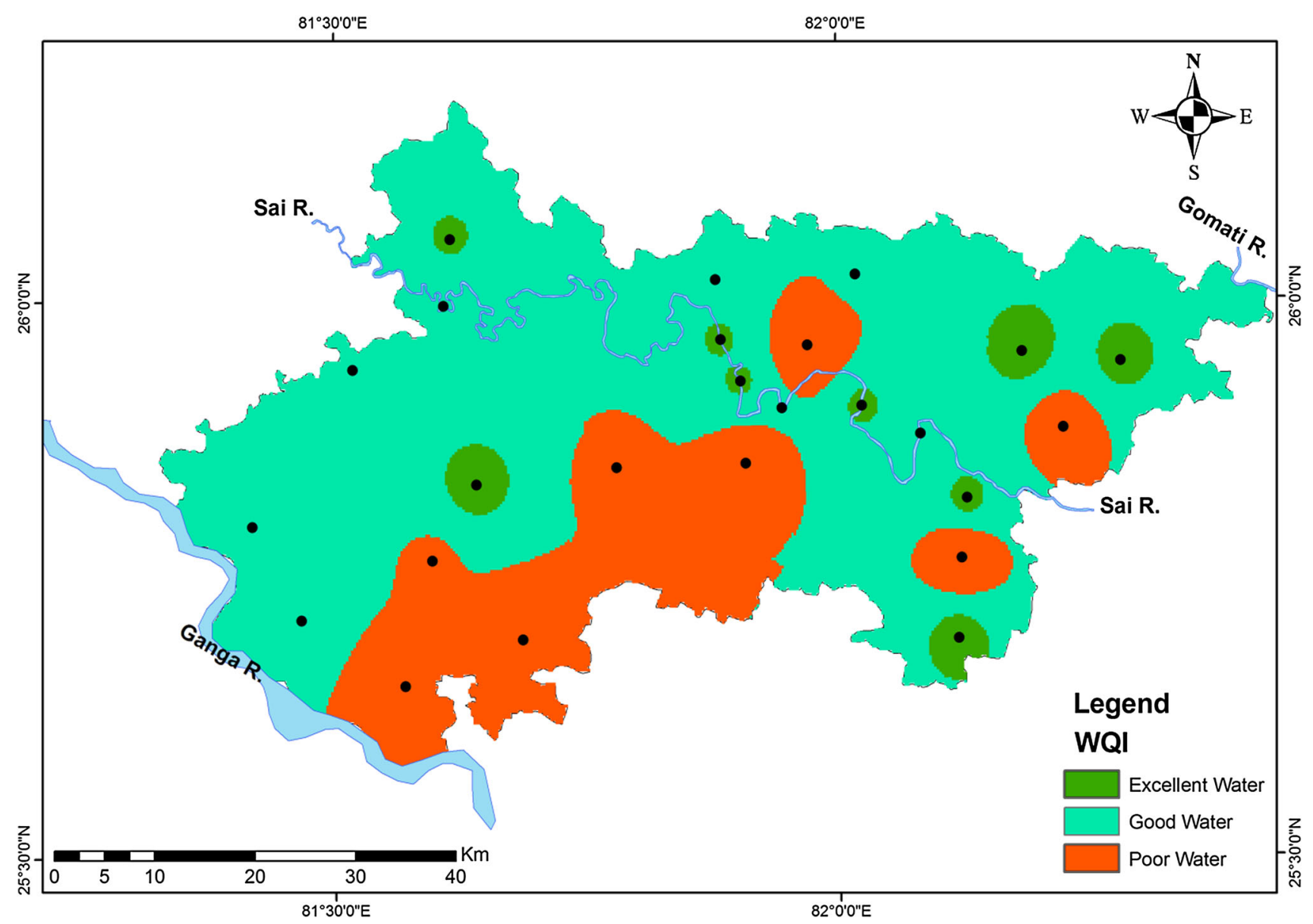

Fig. 8 Water Quality Index map for the Pratapgarh district surface water

calculated for the samples collected from the Bahaurpur, Sarav Naravan, Bahuta, Rajangarh, Chandpur, Manikpur and Pratapgharh sampling locations (Table 8). Among all of the surface water samples, the percentage (\%) of WQI categories is Excellent $(40 \%)$, Good $(32 \%)$ and Poor $(28 \%)$. More than half the location falls under Excellent to Good category (Fig. 8).

\section{Conclusions}

The surface water of Pratapgarh district is mildly acidic to alkaline in nature. The chemistry of surface water is dominated by $\mathrm{Na}^{+}$and $\mathrm{Ca}^{2+}$ and $\mathrm{HCO}_{3}{ }^{-}$and $\mathrm{Cl}^{-}$. In majority of surface water samples, concentration of alkaline earth metals $\left(\mathrm{Ca}^{2+}+\mathrm{Mg}^{2+}\right)$ exceed alkali metal cations $\left(\mathrm{Na}^{+}+\mathrm{K}^{+}\right)$and $\mathrm{HCO}_{3}{ }^{-}$dominates over $\left(\mathrm{SO}_{4}{ }^{2-}+\mathrm{Cl}^{-}\right)$. $\mathrm{Ca}^{2+}-\mathrm{Mg}^{2+}-\mathrm{HCO}_{3}{ }^{-}, \mathrm{Ca}^{2+}-\mathrm{Mg}^{2+}-\mathrm{Cl}^{-}$and $\mathrm{Na}^{+}-\mathrm{HCO}_{3}{ }^{-}-$ $\mathrm{Cl}^{-}$are the dominant hydrogeochemical facies in the surface water of the area. Our results suggest that the chemical composition of the surface water of Pratapgarh is largely controlled by rock weathering with minor contributions from agriculture and anthropogenic sources. In majority of the samples, the analysed parameters are well within the desirable limits and water is potable for drinking purposes. However, concentrations of TDS, TH, $\mathrm{F}^{-}, \mathrm{NO}_{3}^{-}, \mathrm{Na}^{+}$, $\mathrm{Ca}^{2+}$, and $\mathrm{Mg}^{2+}$ exceeded the desirable limit at few sites. The WQI shows that $72 \%$ of surface water samples were found as Excellent to Good categories and can be used for direct consumption, while $28 \%$ water samples are of Poor category. The water which is not suitable for direct consumption requires treatment before its utilization.

Acknowledgments The authors are grateful to Dr. Amaledu Sinha, Director, Central Institute of Mining and Fuel Research for his kind support and permission to publish this paper. Authors also are thankful to Council of Scientific and Industrial Research, New Delhi for the financial support under IAP mode of 11th Five Year Plan Project. We thank Dr. B. K. Tewary, Dr. Mukesh Kumar Mahato and other laboratory colleagues for their support and encouragement. Our hearty thanks to the Editor-in-Chief and anonymous reviewer for their valuable suggestions to improve the study in the present form. 
Open Access This article is distributed under the terms of the Creative Commons Attribution 4.0 International License (http:// creativecommons.org/licenses/by/4.0/), which permits unrestricted use, distribution, and reproduction in any medium, provided you give appropriate credit to the original author(s) and the source, provide a link to the Creative Commons license, and indicate if changes were made.

\section{References}

Agrawal V, Jagetia M (1997) Hydrogeochemical assessment of groundwater quality in Udaipur city, Rajasthan, India. In: Proceedings of National Conference on Dimension of Environmental Stress in India. Department of Geology, MS University, Baroda, pp 151-154

APHA (1998) Standard methods for the examination of water and waste water, 20th edn. American Public Health Association, Washington

Babiker IS, Mohamed MAA, Hiyama T (2007) Assessing ground water quality using GIS. Water Resour Manag 21:699-715

Ballukraya PN, Ravi R (1999) Characterisation of groundwater in the unconfined aquifers of Chennai city, India: part 2-factor analysis. J Geol Soc India 54:13-22

BIS (2003) Indian standard drinking water specifications IS10500:1991, edition 2.2 (2003-2009). Bureau of Indian Standards, New Delhi

Bonham-Carter GF (1996) Geographic information systems for geoscientists: modelling with GIS. Comput Methods Geosci 13:1-50

Chandra S, Singh PK, Tiwari AK, Panigrahy B, Kumar A (2014) Evaluation of hydrogeological factor and their relationship with seasonal water table fluctuation in Dhanbad district, Jharkhand, India. ISH J Hydraul Eng 21(2):193-206. doi:10.1080/ 09715010.2014.1002542

Chatterjee R, Gourab T, Paul S (2010) Groundwater quality assessment of Dhanbad district, Jharkhand, India. Bull Eng Geol Environ 69:137-141

Freeze RA, Cherry JA (1979) Groundwater. Prentice-Hall, Englewood Cliffs

Ghosh A, Tiwari AK, Das S (2015) A GIS based DRASTIC model for assessing groundwater vulnerability of Katri Watershed, Dhanbad, India. Model Earth Syst Environ 1(3):1-14. doi:10.1007/ s40808-015-0009-2

Gnanachandrasamy G, Ramkumar T, Venkatramanan S, Vasudevan S, Chung SY, Bagyaraj M (2014) Accessing groundwater quality in lower part of Nagapattinam district, Southern India: using hydrogeochemistry and GIS interpolation techniques. Appl Water Sci 5:39-55

Gupta M, Srivastava PK (2010) Integrating GIS and remote sensing for identification of groundwater potential zones in the hilly terrain of Pavagarh, Gujarat, India. Water Int 35:233-245

Krishna Kumar S, Logeshkumaran A, Magesh NS, Prince S, Godson PS, Chandrasekar N (2014) Hydro-geochemistry and application of water quality index (WQI) for groundwater quality assessment, Anna Nagar, part of Chennai City, Tamil Nadu, India. Appl Water Sci. doi:10.1007/s13201-014-0196-4

Kumar R, Singh RD, Sharma KD (2005) Water resources of India. Curr Sci 89:794-811

Kumar SK, Bharani R, Magesh NS, Godson PS, Chandrasekar N (2014) Hydrogeochemistry and groundwater quality appraisal of part of south Chennai coastal aquifers, Tamil Nadu, India using WQI and fuzzy logic method. Appl Water Sci 4:341-350
Majumdar D, Gupta N (2000) Nitrate pollution of ground water and associated human health disorders. Indian $\mathrm{J}$ Environ Health 42:28-39

Maragella M, Vitale C, Petrarulo M, Rovera L, Dutto F (1996) Effects of mineral composition of drinking water on risk for stone formation and bone metabolism in idiopathic calcium nephrolithiasis. Clin Sci 91:313-318

Milovanovic M (2007) Water quality assessment and determination of pollution sources along the Axios/Vardar River, Southeastern Europe. Desalination 213:159-173

Mishra PC, Patel RK (2001) Study of the pollution load in the drinking water of Rairangpur, a small tribal dominated town of North Orissa. Indian J Environ Ecoplan 5:293-298

Nadiri AT, Moghaddam AA, Tsai FTC, Fijani E (2013) Hydrogeochemical analysis for Tasuj plain aquifer, Iran. J Earth Syst Sci 122:1091-1105

Nasri N, Bouhlila R, Riadh A (2015) Multivariate statistical analysis of saline water-a case study: Sabkha Oum Lekhialate (Tunisia). Int J Environ Sci Dev 6:40-43. doi:10.7763/IJESD

Okiongbo KS, Douglas RK (2015) Evaluation of major factors influencing the geochemistry of groundwater using graphical and multivariate statistical methods in Yenagoa city, Southern Nigeria. Appl Water Sci 5:27-37. doi:10.1007/s13201-0140166-x

Parmar KS, Bhardwaj R (2014) Water quality management using statistical analysis and time-series prediction model. Appl Water Sci 4(4):425-434. doi:10.1007/s12665-012-1967-6

Piper AM (1944) A graphical procedure in the geochemical interpretation of water analysis. Trans Am Geophys Union 25:914-928

Rao NS (1997) Studies on water quality index in hard rock terrain of Guntur district, Andhra Pradesh, India. National Seminar on Hydrogeology of Precambrian Terrains and Hard Rocks Areas, Dharwad, pp 129-134

Ravikumar P, Mehmood MA, Somashekar RK (2013) Water quality index to determine the surface water quality of Sankey tank and Mallathahalli lake, Bangalore urban district, Karnataka, India. Appl Water Sci 3(1):247-261

Sawyer CN, McCarty PL (1967) Chemistry of sanitary engineers, 2nd edn. McGraw Hill, New York

Selvam S, Manimaran G, Sivasubramanian P (2013) Hydrochemical characteristics and GIS-based assessment of groundwater quality in the coastal aquifers of Tuticorin corporation, Tamilnadu, India. Appl Water Sci 3(1):145-159

Singh DF (1992) Studies on the water quality index of some major rivers of Pune Maharashtra. Proc Acad Environ Biol 1:61-66

Singh AK, Hasnain SI (1999) Environmental geochemistry of Damodar river basin, east coast of India. Environ Geol 37:124-136

Singh G, Kamal RK (2014) Application of water quality index for assessment of surface water quality status in Goa. Curr World Environ 9(3):994-1000. doi:10.12944/CWE.9.3.54

Singh AK, Mondal GC, Kumar S, Singh TB, Tewary BK, Sinha A (2008) Major ion chemistry, weathering processes and water quality assessment in upper catchment of Damodar River basin, India. Environ Geol 54:745-758

Singh AK, Raj B, Tiwari AK, Mahato MK (2013a) Evaluation of hydrogeochemical processes and groundwater quality in the Jhansi district of Bundelkhand region, India. Environ Earth Sci 70(3):1225-1247

Singh PK, Tiwari AK, Mahato MK (2013b) Qualitative assessment of surface water of West Bokaro Coalfield, Jharkhand by using water quality index method. Int $\mathrm{J}$ Chem Tech Res 5(5):2351-2356 
Singh PK, Tiwari AK, Panigarhy BP, Mahato MK (2013c) Water quality indices used for water resources vulnerability assessment using GIS technique: a review. Int $\mathrm{J}$ Earth Sci Eng 6(6-1):1594-1600

Singh P, Tiwari AK, Singh PK (2014) Hydrochemical characteristic and quality assessment of groundwater of Ranchi township area, Jharkhand, India. Curr World Environ 9(3):804-813. doi:10. 12944/CWE.9.3.30

Singh P, Tiwari AK, Singh PK (2015a) Assessment of groundwater quality of Ranchi township area, Jharkhand, India by using water quality index method. Int J Chem Tech Res 7(01):73-79

Singh PK, Panigrahy BP, Tiwari AK, Kumar B, Verma P (2015b) A statistical evaluation for the groundwater quality of Jharia coalfield, India. Int J Chem Tech Res 7(4):1880-1888

Singh SK, Srivastava PK, Singh D, Han D, Gautam SK, Pandey AC (2015c) Modeling groundwater quality over a humid subtropical region using numerical indices, earth observation datasets, and X-ray diffraction technique: a case study of Allahabad district, India. Environ Geochem Health 37(1):157-180. doi:10.1007/ s10653-014-9638-Z

Srinivas Y, Oliver DH, Raj AS, Chandrasekar N (2013) Evaluation of groundwater quality in and around Nagercoil town, Tamil Nadu, India: an integrated geochemical and GIS approach. Appl Water Sci 3:631-651

Srivastava PK, Mukherjee S, Gupta M, Singh SK (2011) Characterizing monsoonal variation on water quality index of River Mahi in India using geographical information system. Water Qual Expo Health 2:193-203

Tiwari TN, Mishra MA (1985) A preliminary assignment of water quality index of major Indian rivers. Indian J Environ Prot 5:276-279

Tiwari AK, Singh AK (2014) Hydrogeochemical investigation and groundwater quality assessment of Pratapgarh district, Uttar Pradesh. J Geol Soc India 83(3):329-343
Tiwari AK, Singh PK, Mahato MK (2014) GIS-based evaluation of water quality index of groundwater resources in West Bokaro Coal field, India. Curr World Environ 9(3):843-850. doi:10. 12944/CWE.9.3.35

Tiwari AK, De Maio M, Singh PK, Mahato MK (2015) Evaluation of surface water quality by using GIS and a heavy metal pollution index (HPI) model in a coal mining area, India. Bull Environ Contam Toxicol. doi:10.1007/s00128-015-1558-9

Tiwary RK (2001) Environmental impact of coal mining on water regime and its management. Water Air Soil Pollut 132:185-199

Tjandra FL, Kondhoh A, AMA Mohammed (2003) A conceptual database design for hydrology using GIS. In: Proceedings of Asia pacific association of hydrology and water resources, Kyoto, Japan, 13-15 March

Todd D (1980) Ground water hydrology, 2nd edn. Wiley, New York 535

Vasanthavigar M, Srinivasamoorthy K, Vijayaragavan K, Ganthi RR, Chidambaram S, Anandhan P, Vasudevan S (2010) Application of water quality index for groundwater quality assessment: Thirumanimuttar sub-basin, Tamilnadu, India. Environ Monit Assess 171:595-609

Verma AK, Singh TN (2013) Prediction of water quality from simple field parameters. Environ Earth Sci 69:821-829

WHO (1997) Guidelines for drinking-water quality. Recommendations, vol 1. World Health Organisation, Geneva, pp 1-4

Yadav KK, Gupta N, Kumar V, Arya S, Singh D (2012) Physicochemical analysis of selected ground water samples of Agra city, India. Recent Res Sci Technol 4(11):51-54

Yadav KK, Gupta N, Kumar V, Sharma S, Arya S (2015) Water quality assessment of Pahuj River using water quality index at Unnao Balaji, MP, India. Int J Sci Basic Appl Res 19:241-250 